\title{
ETHNOGRAPHIC RESEARCH AMONG DRINKING YOUTH CULTURES: REFLECTIONS FROM OBSERVING PARTICIPANTS
}

\author{
Daniel Briggs, Ivan Gololobov, Aimar Ventsel
}

"You can't trust a person when he didn't have a hair of the dog." (Venechka Erofeev, Moskva-Petushki)

\begin{abstract}
Increasingly, ethnographic methods in the social sciences are being robbed of their capacity to research problematic social groups given the increased "risk governance" to ethical and methodological practices. Positivism and constructing objective realities of these groups has become the order of the day, which has resulted in a 'conceptual distance' from these kinds of social groups. In this article, we advocate for a return to subjectivity using ethnography, and do so through highlighting examples from our experience from numerous projects undertaken with different youth cultures where alcohol is central to individual identities and collective social norms. We show, on the one hand, that this kind of research is possible but it requires the researcher to adopt versatility and fieldwork flexibility, while on the other, in some ways to abandon their ethical conceptions of what they are expected to objectively do and instead engage with the group under study. In the paper, we challenge various ethical and methodological dilemmas related to this kind of research.
\end{abstract}

Keywords: epistemology, ethnography, 'observing participants', positionality, youth drinking culture

\section{INTRODUCTION}

Ethnographic research with different youth drinking cultures and in environments heavily associated with excessive drinking - such as those with which we have worked - immediately puts the researcher in situations of choice with regard to the ongoing consumption of alcohol and how to situate themselves with their participants. It is our deep belief that there are no universal guidelines on how a researcher should behave in these situations when his or her participants are engaged in regular, heavy alcohol consumption. We assume that each scholar makes their own decisions on the questions raised by such 
challenges. However, methodological and epistemological questions of a study among such drinking cultures transcend the subjectivity of individual choice. How a scholar deals with the challenges posed by an extreme research environment can be justifiably argued on the basis of the author's unquestionable assumptions such as the belief that drinking is a sinful practice. However, the knowledge produced in such studies, as long as it is intended to fall within the scope of academic work, means that the validity of its conclusions should satisfy the demand of critical assessment. In this article, we intend to present critical reflections of our ethnographic actions in the field with youth drinking cultures. We do this in the context of Russian, British and German youth. We do not adopt any theoretical position because our reflections are methodological and are attributable to thick descriptions (Van Maanen 1988), our goal being to "uncover the conceptual structures that inform our subjects' acts, the 'said' of social discourse, and to construct a system of analysis in whose terms what is generic to those structures, what belongs to them because they are what they are, will stand out against the other determinates of human behaviour" (Geertz 1973: 27).

We firstly set some context by discussing ethnographic research in the context of youth cultures before outlining the aims we had and methods we used with our respective participants. In the main body of our article we concede that, although our work is situated among different cultures in different social occasions, they share some similarity with regard to the way in which we had to engage with young people and this prompts us to recognise the importance they attribute to their drinking practices and 'drinking stories'. Because of this, we argue that to glean more subjective experiences associated with youth drinking cultures, we too must engage with them in such practices.

\section{SOME BRIEF NOTES ABOUT ETHNOGRAPHY}

Ethnographic methods are well established and appreciated in both sociological and criminological drug and alcohol research studies and have provided groundbreaking insights into the various social and cultural practices of different social groups (Anderson 1990; Becker 1953; Bourgois 1995; Briggs 2012; Griffin et al. 2009; Maher 2002; Power 2002; Preble \& Casey 1969; Rubin \& Comitas 1975; Ward 2010; Young 1971). In addition, ethnographic research methods have also been helpful in understanding youth cultures (Briggs 2013; Hayward 2002; Ward 2010; Willis 1977). Despite this, ethnographic methods which make use of participant observation still receive much opposition within social science research on substance users (Bourgois 1995). This has been linked to the 
increased governance of social science research which has taken on an ever more intensified 'risk-assessment' approach (Israel 2004; Israel \& Hay 2006; Lee-Treweek \& Linkogle 2000). Indeed, across the disciplines of anthropology, criminology, and sociology, there has been much criticism of such research studies which have feared interaction with participants (see Blackman 2007; Curtis 2002; Palmer \& Thomson 2010; Sanjek 2000). Various ethical codes that the authors of this article have signed for research purposes in different countries either directly forbid drinking with informants (like the Code of Ethics from AAA in 2000) or condemn such behaviour.

Indeed, we have found that many ethics committees have frowned, and even rejected work we have attempted to undertake, on the grounds that it is 'too dangerous' or raises 'too many ethical issues'. Probably this explains why, to date, few ethnographic studies have been undertaken with youth drinking cultures (Clapp et al. 2007; Hesse et al. 2008; Tutenges \& Hesse 2008). Yet, even these studies seem to lack subjective interaction with participants - preferring, in the main, to be objective to social interactions with their participants. They also lack reflection on their role in the field and whether they drank with participants. We face other barriers as well when we try to publish, some journals considering our work 'unscientific' or 'unsuitable'. Shane Blackman (2007: 700) has called this 'hidden ethnography', whereby data is "not released or published because it is considered too controversial". However, we believe that - from the first instance - controversial drinking with informants is an important part of ethnographic research because in contemporary ethnography it is assumed that a researcher in the field cannot be neutral; he or she inevitably affects the field and the practices observed by the very fact of researching their presence (Coffey 1999).

In this article, we show how the particular presence of researchers in the field and their interactions with participants affect actual practices of heavy alcohol abuse, the reality we observe, and the identity of the observed. In the following thematic reflections, which use observations and verbatim quotes based on three research projects with youth drinking cultures conducted in Russia, UK, and Germany, we show the challenges ethnographers face while interacting within youth drinking cultures (Fetterman 1989). As Patton (1990: 474) notes, ethnographic researchers "should strive neither to overestimate nor to underestimate their effect [on the research study] but to take seriously their responsibility to describe and study what those effects are". Such a discussion should assist other scholars to make informed methodological and ethical choices on their strategies (Vanderstaay 2005) when working with similar groups and in environments where regular, heavy alcohol consumption is the norm (Palmer \& Thomson 2010). 


\section{AIMS, METHODS AND CONTEXT OF OUR RESPECTIVE STUDIES}

In line with other ethnographic studies in the context of youth and alcohol, our methods with youth drinking cultures made use of interviews and focus groups, as well as field observations. The Russian cases are represented in the research conducted by Ivan Gololobov. His study focused on punk scenes, music and artistic underground. It has to be said that punk scene and music underground in general has always been a heavy-drinking culture. Since the late 1970s, when the first punk bands emerged in the USSR, alcohol was an essential part of a counter-cultural identity and an integral element of punk poetic lifestyle. Today, it remains a regular attribute of punk concerts, events, and hanging around or tusovki, as well as a usual accessory of individual subcultural 'doing nothing'.

The study of Russian punk conducted scenes by Ivan Gololobov was based on an extensive period of 'observant participation' (Gololobov 2014) and two specifically designed field trips. The first part took place in Krasnodar, south of Russia (August-November 2009), and the second in Saint Petersburg (MarchJune 2010). Ivan joined several youth groups who were affiliated with local punk scenes and followed their creative, leisure, and other activities for several months. However, apart from simply observing their everyday lives, more than 40 interviews with musicians, activists, music journalists, managers, producers, fans, gig goers and regular members of subcultural communities belonging to or related to the punk scenes were documented. Indeed, during this research, it was rare that an interview, conversation, or informal meeting took place without drinking alcohol and most observations were accompanied by excessive alcohol consumption (Gololobov et al. 2014: 124-128).

Similarly, Daniel Briggs conducted his research in and among the excessive alcohol consumption of British young people, except his study was analysing the 'holiday experience'. The arrival of mass tourism from the UK in the 1960s heralded new opportunities for large numbers of British youth to holiday abroad. This was principally around the Mediterranean countries of Greece, Italy, and Spain. In particular, the Balearic Islands of Majorca and Ibiza started to increase in popularity during the 1980s with the arrival of Ecstasy and house music. These islands have since developed a cultural association for music, drugs, and alcohol. As a consequence, many British youth developed an attitude to drinking large quantities of alcohol when on holiday abroad because it signals both 'time to party' and 'time away' from life's routines and responsibilities.

Previous UK research on the drinking attitudes of British youth abroad was largely survey oriented and had failed to sufficiently examine why these 
behaviours took place (see Briggs 2013 for the whole story). It can also be noted that the ethnographic research which had taken place on the drinking attitudes of youth on holiday abroad was largely Danish and American. The project on drinking attitudes of British youth abroad aimed at addressing these two issues. Firstly, because the way in which British youth' drinking behaviours had been constructed was largely misunderstood. And secondly, because there was immense public health concern about excessive youth drinking both in the UK and abroad. Having undertaken pilot focus groups $(n=6)$ in the UK, the scholars, led by Daniel Briggs, then proceeded to undertake a short field trip in Ibiza, using ethnographic methods with British youth. The members of the research team undertook observations with British youth in different drinking contexts, which involved 17 focus groups $(n=97)$ in five days. Because many of these young people travelled in groups, field researchers felt it was best to undertake focus groups rather than select people individually and coax them away from their group for one-to-one interviews. Some young people in our sample travelled in groups of up to 20 people, which meant it was problematic to try and prise individuals away from their group. The scholars undertook one focus group with 15 young men - and even then there were a few missing from their party. In this respect, focus groups also enabled researchers to capture the 'group moment' and a real 'atmosphere' of drinking in the holiday context.

The study of drinking practices among youth in East Germany was conducted by Aimar Ventsel. His research also focused on various subcultural youth associations such as punks and skinheads. With regard to the alcohol consumption punk culture in Germany is not much different from the punk scenes in Russia. Alcohol consumption is an integral part of everyday practices, concerts, and other events. It must be mentioned that use of light alcohol, most notably beer, plays a significant role in German working class culture, which is where most of the informants came from. However, unlike Russia, in Germany both working class men and subcultural youth have a tradition of hanging out in pubs, a habit that is also adapted to German punk culture. Moreover, demonstrative consumption of local drinks as part of local identity has shifted from the mainstream society to underground youth subcultures. Therefore, as it will transpire in this text, public abstinence created unnecessary tensions that could have affected the relationship with people under study.

Aimar Ventsel conducted his fieldwork in the East German city of Halle from November 2009 to January 2010 and in December 2010. In the 1980s GDR era, Halle used to be one of the 'punk capitals' of the socialist period and this research was an indirect follow-up of a study undertaken in 2006 and 2007, which examined the economic networks in which members of the local punk scene were involved (see Ventsel 2008). The more recent research focused on 
different groups within the town's scene and their links to other cities, with the aim to document East German punk as a semi-autonomous social field. This research mainly focused on hanging around with a particular group in one of four alternative clubs/pubs of Halle. The core group of the informants were all male in the age between 27 and 35 . However, through their young girlfriends and other people in local punk community, the researcher also gained access to the 'young punks' (from 17 to 25 ) and 'old people' (40-somethings), in this way documenting all three generations of local punks. Overall, around 30 interviews were conducted. However, in the same way as in the Russian case participant observation remained the main research method. It included hanging around with punks, going to concerts, visiting their homes, and unrecorded spontaneous discussions.

Alcohol plays an important role in the social practices of German punks. Consuming certain local alcoholic beverages is also a marker for identity; or, as one of the informants said: "When a normal citizen meets his friend to discuss things over coffee, then we meet friends in a pub to discuss things over beer." (Olli, personal communication, 12.10.2010) Although drinking use was not the main focus of Ventsel's research because of its inextricable link to the identity construction, his research paid attention to the forms and norms of alcohol consumption. Moreover, part of his research focused on illegal economies, which is a very sensitive topic for local punks. It is not overstated to argue that some of the informants were extremely suspicious of people from 'outside' showing interest in their un-taxed income, and 'fitting in' was needed for successful research. It can be argued that hardly any formal interview would have been possible before getting to know a person and that usually happened in a club or a bar. We now proceed to outline the principle arguments of our article, beginning with showing on neutral terms that drinking among our respondents was an entirely normal social practice, which aided communication and the development of relations.

\section{DRINKING AS A SOCIAL PRACTICE: FOR BONDING}

Sociologically speaking, drinking is first of all a practice of communication. Whether it is a ritual glass of wine, wild wedding party or a pub crawl, drinking alcohol serves to establish certain communicative relations within a drinking community as well as outside of a drinking group. On the other hand, alcohol is different from other intoxicating substances in that in countries where we conducted our research, alcohol - as opposed to drugs - is legal and legitimate. Youth drinking might be viewed by the majority in the UK, Russia, or Germany 
as a 'deviant' behaviour and therefore condemned but researchers' involvement and interactions with these groups do not violate laws - that is to say, we have not researched minors and alcohol consumption as our participants have been of the legal drinking age. It is unnecessary to mention that many young people in our respective cohorts saw little harm in the heavy consumption of alcohol. In the Russian context it is often strongly associated with being in a group:

For example, how I got introduced to local punk movement. It all started when I was 13 and met this Vova, he had a crew in this famous cafe on the corner, punks were also hanging around there. Very soon though I got bored with Vova because of his speeches. Punks were more interesting. We got drunk together and all the things like that. (Val, personal communication, 30.10.2009)

Drinking is also often associated with close interpersonal relations and friendship.

I have a friend Dima, he was a punk before, [---] we used to get pissed together, vomited, used to wake up in the morning, were drinking cheap booze, sleeping in dirty garages, were dressed in dirty stuff. (Alex, personal communication, 20.08.2009)

In the context of British youth abroad, heavy alcohol consumption is the norm and serves to alleviate mundane lives at home while, at the same time, ignite the party atmosphere of the holiday:

At home, I have work. When I am away, I have two weeks away to get pissed [drunk]. I don't have to get up in the morning, and don't have any worries. Sun, sea, and sangria! It is a different atmosphere. (Tina, personal communication, 06.06.2011)

Because you are on holiday, you think I am here to drink, I am here to party. I am here to go out clubbing. That's what it's all about. That is what you are going there for, drink, relax, and have fun. (Steve, personal communication, 05.06.2011)

And German punks and skinheads are no exception:

I work here in the village and do quite a boring job. At the weekend, then I go with my mates, this is the time I am looking forward to the whole week. We go to concerts, have beer, have fun. Or we just meet, talk, and have a few beers. This is what punkrock is about, to go to parties, meet people and make contacts. (Paul, personal communication, 12.11.2007) 
Over the course of our projects, we found that such excessive alcohol consumption - while considered the norm among these social groups - has important implications for youth identities. Therefore, by using ethnographic methods with such groups and emphasising the subjective experience, we can learn how narratives are constructed to make sense of the 'experience of drinking'.

\section{DRINKING AS AN ASOCIAL PRACTICE: BREAKING BAD}

Paradoxically, and despite the aforementioned orientation to establishing social bonds, excessive drinking also regularly involves forgetting, subversion, and destruction of one's identity. This, as numerous scholars agree, aims at creating a libratory risk (Beck 1998 [1992], 1999; Giddens 1991, 1999). This risk, however, is not only existential, but also methodological as it regularly creates dangerous situations for the researcher. A good example is a drunken story told by Sab - a regular gig goer and an activist of Krasnodar punk scene in Russia - as recorded in a diary:

Ivan (author and researcher): What was your biggest punk experience?

Sab: I will tell you. Once with Val within two days we got drunk, punched, and saw the sea. All within two days. The story is the following. We are having a drink and then decide to go to Utrish [a popular wild beach and camping site near Anapa and Novorossiisk], buy some wine, drink it all in the bus, so when we are there we are already good enough. We walk to the beach and pass by a bunch of local youth. They don't touch us, we don't touch them, but some steps away Val suddenly turns back and shouts: 'Hey you, do you love Lenin enough!' Obviously they turned back and punched our faces. We continue further, get to some other locals who are drinking samogon [homemade spirit]. They stuff us with this more so that we completely lose touch with reality. But we remembered that we didn't have wine anymore, so we decided to go to the village and buy some more. There we met the guys with whom we had had a fight recently, they were already ok, advised us where we could buy some, we went there, got a couple of plastic bottles, and obviously started drinking it straight away. On the way back I fell asleep, woke up when the coast guards were slightly kicking me in the face with their machine guns, they were on duty. I said: 'I am okay, just had a bit too much', they left me alone, and continued their way. I then realised that Val went some steps further than me and is probably lying somewhere not that far away and if he is in a bad mood, we are in trouble, because these guys don't like his type of jokes. I shouted: 
'Hey, guys, there is another one like me behind the bushes, he is also okay, just don't pay attention to him.' They laughed and passed him by. That was cool. So that was an experience where within a couple of days we managed to get pissed several times, got our faces punched, saw the sea, and I forgot to mention that when I fell I badly scratched my face, which took weeks to recover. That's a punk experience I had. And I have plenty of stories like that. (Sab, personal communication, 21.08.2009)

Another example is a story of Il78, a lead singer from a punk-band and a DIY activist from Saint Petersburg.

I178: Well, I remember Boris; that was a funny thing. We got drunk and went to Lena's place. She lived on the third floor, you know - this kind of old buildings, long staircases, so we had to go up. But we were pissed, $B[. .$.$] got tired and stopped to have some rest on the way, and we contin-$ ued. Some hours later we hear him screaming, we go out and find him, he looks horrified. We ask: 'What happened?' He says: 'Imagine, I wake up somewhere, I have no idea how I got there. I see the stairs, realise that I haven't been here before. I look up and see a grey concrete ceiling. I think: Oh my god, it is a cell, I am in a prison cell. What did I do yesterday? Maybe I killed someone and was arrested for that? Oh my god!' He didn't realise that this was simply a staircase on the way to Lena's flat. (I178, personal communication, 08.05.2010)

The research on the drinking attitudes of British youth abroad also shows a degree of actual danger cased by the excessive drinking. A group of British girls reflect on being drunk and then beaten up by nightclub bouncers and the police in Ibiza. The researchers in this excerpt await the social reaction of the event among the group before displaying their reaction. The result is that a common ground is shared:

Sunglasses 1: They needed three...massive...men to tackle her. Was that necessary? Then I was out there, because I speak Spanish, by then I am completely sobered up, things are crystal clear to me. I was trying to get the other girls out or us back in and speak to the manager.

[There is then some confusion in the story; about what happens next and some small debate goes on about the order of events]

Blue-eyed 1: Then the police said to us, 'well the bouncers say you are whores', and I said, 'what kind of police are you', and they were like 'fuck your mother'. 
Sunglasses 1: Then I started screaming out abuse to this policeman about his mother in Spanish. Like, if you're gonna give it, you're gonna have to take it.

[Several of the girls laugh at this]

Daniel (author and researcher): [Sounding confused] Er, ok, fair enough.

Blue-eyed 1: So this is why we got arrested. He [the policeman] goes 'have you got your passport?' and I was like, yeah, yeah, I have my passport here [imitates pretending to search her pockets, take out the passport but instead suddenly raises her middle finger with a fierce face].

[All sorts of giggle at this - including Daniel, although I try to keep my reactions neutral]

Blue-eyed 1: Then he leaned in and said 'what did you say', grabbed my hand, [hand]cuffed me and started shoving me all the way to the car, and I was like 'I'm sorry, I'm sorry', and he was like 'fuck your mother and your father'.

Sunglasses 1: I went after her and I was like, 'why are you taking her?' Blue-eyed 1: All I remember was being put in a headlock, being dragged to the car and he kicked me into the car.

Other 1: How could you do that to a girl???!!!

Blue-eyed 1: I was just so pissed off [upset], looking out of the window, then he goes over to Sunglasses 1...

Sunglasses 1: I was just lying there crying, he grabs me, drags me, all my knees were cut [shows us], and then it was like dripping blood.

Broad accent 1: And I went up to the manager and bouncers or whoever and said, 'this is ridiculous, you have no idea about what is going to happen', and he was laughing in my face and saying 'what you gonna do'.

Sunglasses 1: So then I tried to find out where they had taken her, and I went to the nearest police station trying to find out where they had taken her. They said 'we don't speak English', so I said fine I speak Spanish. I explained what happened in Spanish and he said 'No'. So I said where can I see her, and he said '30 minutes' walk'. So I said you are going to let me walk with these bleeding knees on this dark road, get raped or killed on this dark road by myself in the middle of the road.

(personal communication, 01.06.2010) 
These stories are sometimes too brutal, but the researcher has to accept them because these drinking-related practices can be important for the group relations:

Olli: I remember when Hammerhead [a German punk band that enjoys a cult status because of direct and politically provocative texts and stage show] played here in Halle. This was in VL [a left wing club], there were lots of hippies [a prerogative expression to 'politically correct' part of the scene]. When the band got to the stage, they were already drunk and the singer was full of coke. We started drinking already early noon to celebrate the concert in the evening. When we turned up, we were already drunk as hell. The singer shouted, 'Welcome to the Hammerhead concert in the Eastern Zone [West German cold war expression to the GDR]'. Hippies shouted something but Loof knocked one down. The band started to play, it was hilarious! In the middle, the drummer threw up upon the drums but kept playing. The puke was on drums and when he hit them, it flew up and covered him. Hilarious. We had a party and when we went home, Loof and Micro were so drunk, I had to carry them. In the time when one fell down and I helped him to get up the other fell down. It took ages to get home!

Aimar: [Unconvincingly] So you enjoyed it...

Olli: Absolutely!

Aimar: Pity I was not there....

(personal communication, 04.10.2009)

These examples highlight the importance of drinking-related danger in constructing identities when researching these youth groups. However, they also show that these practices are far from being considered 'normal' environments for conducting an ethnographic research. The question then becomes, what should be the position of an ethnographer in such situations? It is obvious that we need to establish rapport with participants of our research. It is clear that in doing so we also become part of the interactions. And in these kinds of challenging interactions we as ethnographic researchers have to make difficult decisions in the context on our own place with regard to the research and the researched. 


\section{OBSERVING PARTICIPANTS: TO DRINK OR NOT TO DRINK?}

In this section we reflect on our decisions whether or not to join the practices of excessive consumption of alcohol while conducting research among groups of young people drinking alcohol. We know that the abuse of alcohol implies certain unpredictability of the consequences of its excessive consumption and that group dynamics often play a significant role in alcohol consumption among youth. Therefore the first challenge the researcher faces is how to manage relations and make decisions with potentially drunken participants in intoxicated environments. In the situation of an ongoing carnival of drinking, which does not tolerate hierarchical difference between youth groups, staying outside of the common practice of drinking means either to be excluded from the celebrating group or to be put at risk, if not to potentially destroy, the event itself. Indeed, our youth drinking groups are sensitive about their homogeneity. A non-drinker or a person who is falling out of the general behaviour code of the group (for example, someone who falls asleep while the others are still drinking; who stops participating in drinking, or who refuses to do certain stupid things when the others are 'up for it') becomes downgraded in his or her status and is often excluded from the group. In this example with a focus group of British youth, some young men reflect on taking drugs (instead of drinking), which had implications for group norms:

Fat man: We started drinking at 11 a.m. in the hotel because we are all inclusive.

Daniel: So roughly how many of them did you drink in the day before you went out?

Fat man: I had about 8 of these small beers, 7 malibu and pineapples, 7 vodka and fantas, a couple of vodka and orange...

Daniel: This is before you went out.

Fat man: Yeah. But this is over 12 hours.

Hat man: You weren't really drunk though when we went out.

Fat man: I was feeling it a little bit when we went out. We went to a bar and paid $6 €$ each and got a pint of vodka and red bull and between us got two bottles of peach schnapps, some shots. So I had the pint of vodka and red bull and then about 8 shots from the two bottles.

Daniel: Fucking hell. 
Fat man: Yeah, because some people didn't want to do it.

Daniel: After the shots?

Fat man: Well that was it.

Hat man: A few of us were on pills while the others just wanted to get smashed in the bar so when it came around to us we were offered drinks and we declined, it killed the group atmosphere.

(personal communication, 11.06.2010)

However, this rule applies to ethnographic researchers as well as participants of the youth group. At times, we need to participate in the practice of alcohol consumption to facilitate acceptance in the group and acknowledgement of the culture, otherwise the consequences could damage research relations. For example, an example from the Russian research:

Sasha: [A bass player in a band, who just ordered a bottle of vodka]: What are you gonna drink guys?

Roma: Tea will do the job.

Sasha [Half jokingly]: Hmmmm, I don't think we will find a common language. (personal communication, 01.10.2009)

In such a way, the choice of not drinking with participants makes us capable of keeping our research identity and, one may say, staying objective, but on the other hand this choice threatens the ranks of our research credibility and access to the internal group communication. By drinking with participants, we enter into unchartered territory, which is not covered in ethnographic textbooks and is not structured by the universities' ethical guidelines. However, this strategy gives us a greater chance of documenting practices and attitudes closer to those held by the members of the youth group. In one focus group of British youth in Ibiza, before we joined them for a night out drinking, they downplayed their alcohol consumption. However, once we spent time with them drinking in the local bars, we were able to document how much they drank and their attitudes to alcohol:

Within a few hours, we are chatting with some young people from Birmingham. Matt, Scott, Steve, and Sarah. Matt is particularly interesting - having had work 'dry up' in the UK, he came out to Ibiza to pass some time. However, in the month he has been here, he is not too sure how much he has spent. He knows he has a $£ 400$ phone bill at least. His friend Steve, also out here for a month, has spent £6000. This was mainly on clubs, drinking and taxis. As we sit and talk, Matt estimates he has had 
around 4 pints of beer in the afternoon. We are invited out with them in the evening to follow events. Because we are all inclusive, we just get our drinks, and they are not soft things either as the measures are half. By the time we meet at 7.30 p.m., another two pints have been drunk and two cocktails each. We each take another two beers and walk down to the boat which will take us to Café Mambo. Café Mambo is where it is said one should go to enjoy the sunset. However, because of our extended chat and drinking in the hotel, we now note that the sun has started to set... At Café Mambo, we try to add up how much we have drunk and Matt estimates four pints and a cocktail but it is clearly more as he has forgotten our drinking between 7.30 p.m. and arriving here. (field notes, 02.06.2010)

In some cases, not drinking does not only put the researcher in an awkward position but also negatively affects his or her respondents and this can cause tensions within researched groups. One example was in the German case when one of the members of the research group was attending a concert and did not drink heavily, instead choosing to have only one beer. During the concert, and while standing at the counter, he took a few pictures. The following week, he met with the club owners and had the following discussion:

Herbert: You know, some people asked about you in the concert.

Aimar: Why?

Herbert: They asked, 'Who is this guy who does not drink and observes everything?' 'Why is he taking pictures?'

Aimar: Why is it their business?

Herbert: They thought you might be a [spy of] Nazi[s]. This is how it works here. When you do not know someone and he is suspicious, you ask around. They were really like 'why do you let such people in' and we said that you were ok, that we know you.

(personal communication, 11.01.2010)

Therefore we feel it is important to engage and participate in drinking, not only to facilitate relations but to see how youth drinking cultures experience drinking, the social environment that supports it, and those who also make up the social scenery. In this example, one of the authors has been drinking with British youth for four hours. As the evening approaches, he and his companions were challenged by all manner of willing night-time economy employees [PR workers], trying to persuade them where was 'best to go' and which club had 'the best pussy'. One of the research participants has already confessed 
to the researcher that he used to deal drugs back home in the UK, but the relationship has been somewhat bonded by the consumption of alcohol and the participation in their noisy activities up and down the beachfront. This final excerpt captures the essence of what we are trying to do in our studies:

[Thirty seconds later another PR couple approach us with tickets for Eden]

PR woman: I guarantee you, you will pull in there tonight.

Irish PR man: [To all of us in a tone of amazement] Oh mate, you gonna find some hot pussy in there [laughs to himself]. Want to see my cock?

Jay: I'm gonna go, I'm paying. I don't give a fuck, how much. Tell me. I have unlimited money.

PR woman: So you get the bar crawl and entry into both clubs. The water party comes on about 4 a.m. in the morning and that's when the fun really starts.

Jay: [Starts getting his money out and pays for me] Lets PARTY!

Daniel (author and interviewer): You can't pay for me.

Jay: [Hugs me] Come out please, let's go. We have to!! I think you're a top man. I don't know why I like you, mate, but I do. Nothing must come back on me because people can get me in jail and it can affect my family.

(personal communication, 01.07.2012)

\section{DISCUSSION AND CRITICAL REFLECTIONS}

This article has attempted to make reflections on our participation with heavily drinking youth groups in Russia, the UK and Germany. Our work complements others who have undertaken similar studies in the area and, instead of weaving a theoretical framework to our paper, we rely on reflections made from thick descriptions. We used ethnography to understand particular cultures and the ways they function. In this way we as researchers were faced with the dilemmas of engaging in challenging practices at the expense of putting professional credibility at risk. However, at the end of the day we are university academics and no institution would be particularly happy to know that their lecturers were involved in practices of excessive drinking, especially when these practices involve young people. The authors of this article made their choices independently of each other, but these choices were similar. We all agree that we should not 
be fearful of engaging in this level of participation with our research subjects because of the potential benefits we can glean from their subjective experiences of drinking. This approach has been met with significant opposition within our respective fields, possibly because it is considered 'risky' (Israel 2004; Israel \& Hay 2006; Lee-Treweek \& Linkogle 2000), and undoubtedly breaks the established academic norms of ethical conduct, perhaps making it unsuitable or controversial (Blackman 2007).

However, we show in this article that when it comes to engaging with youth drinking cultures it is important to accept drinking as a social practice. It is also important to remain neutral but participatory in reactions to drinking stories and drinking with participants. With regard to the ethical issues of drinking we came to the following conclusions. Firstly, consumption of alcohol is not just a 'bad habit' or one's individual way of escaping reality. Young people in the sites of our research see drinking as a practice in which relations develop and evolve between the individual and a group, and a group culture is negotiated and enacted. In this way, drinking alcohol is celebrated on a social occasion, connects people and facilitates enjoyment - regardless of the negative or perhaps brutal stories. Whether the researcher likes it or not, by working in such environment he/she inevitably takes part in this negotiation. It may be a matter of morals for the researcher. However, it is clear that our morals do not always correspond to the life projects of the young people we research.

Secondly, when we hear brutal or graphic stories of drinking or see the drunken actions of our participants, we show that we are not in a position to judge and have to offer flexibility in the moment, even though we may wholeheartedly disagree with what we hear or see. We may, on occasions, have to endorse it - to play the part: witness Daniel's efforts to drink with participants for four hours as the group walked up and down the beach, with their half-naked bodies soaking the sun as they made lewd remarks to the young women walking past. As we start to learn about the drinking culture, we exhibit reactions and behaviours which will enable us to participate and understand it. Along the way, we make mistakes - such as that of Aimar by drinking one beer at a concert, or Ivan asking for tea when the social expectation was to drink vodka.

In the groups under study, alcohol consumption is not necessarily gender specific. In general, female drinking is not condemned by our research cohorts but valued as a positive sign of being part of the same 'scene'. Therefore, when the male researcher stands in a crowd with a beer bottle in his hand, it does not hinder his contacts with female group members. In many situations, alcoholised events offer an easier way to meet people from the opposite sex and start talking with them. By following unwritten codes of behaviour, like buying drinks 
for women, the researcher is also using the opportunity to make contacts with potential informants in an accepted framework of communication. We do acknowledge the gender conflict in undertaking these practices but merely point out that we do so because it is part of the gendered nature of social relations in these contexts.

Lastly, we have come to find that young people tend to create and follow their own social norms when it comes to drinking alcohol. However, when their own norms are in contradiction with the dominant society's norms, they may correct their behaviour so as not to violate mainstream norms (at least not too openly). This all does not mean that they see their own norms as secondary. On the contrary, young people usually value their own group drinking norms more and appreciate people who do follow these norms. Above we have discussed how important is participating in drinking events, which is necessary for the researcher to maintain his or her credibility among the group under study. Another point to consider is that the researcher knows that young people he/ she tries to study do drink and by not participating in the party they do not prevent them drinking. From their perspective, young people know that the researcher knows that they drink, especially when the interviews are conducted about alcohol consumption. Refusing to raise a glass, drink a pint, and sink a shot can be especially contradictory when a researcher is a long-term friend or acquaintance with young people and has drunk with them in the past before he/she came back as a researcher - or even if they do not honour the social moment of drinking and evade the common expectation to drink. We therefore feel that the researcher who ignores drinking and positions him/herself outside of the event shows his/her hypocrisy due the situation 'they know that I know that they know'.

\section{MANUSCRIPT SOURCES}

Fieldwork materials from 2006-2014 in possession of the authors. 


\section{REFERENCES}

Anderson, Elijah 1990. Streetwise: Race, Class and Change in an Urban Community. Chicago: University of Chicago Press.

Beck, Ulrich 1998 [1992]. Risk Society: Towards a New Modernity. London: SAGE Publications.

Beck, Ulrich 1999. World Risk Society. Cambridge: Polity Press.

Becker, Howard S. 1953. Becoming a Marihuana User. American Journal of Sociology, Vol. 59, No. 3, pp. 235-242. http://dx.doi.org/10.1086/221326.

Blackman, Shane J. 2007. 'Hidden Ethnography': Crossing Emotional Borders in Qualitative Accounts of Young People's Lives. Sociology, Vol. 41, No. 4, pp. 699-716. http://dx.doi.org/10.1177/0038038507078925.

Bourgois, Philippe 1995. In Search of Respect: Selling Crack in El Barrio. Cambridge: Cambridge University Press.

Briggs, Daniel 2012. Crack Cocaine Users: High Society and Low Life in South London. London: Routledge.

Briggs, Daniel 2013. Deviance and Risk on Holiday: An Ethnography of British Tourists in Ibiza. London: Palgrave MacMillan.

Clapp, John D. \& Holmes, Megan R. \& Reed, Mark B. \& Shillington, Audrey M. \& Freisthler, Bridget \& Lange, James E. 2007. Measuring College Students' Alcohol Consumption in Natural Drinking Environments: Field Methodologies for Bars and Parties. Evaluation Review, Vol. 31, No. 5, pp. 469-489. http://dx.doi. org/10.1177/0193841X07303582.

Coffey, Amanda 1999. The Ethnographic Self: Fieldwork and the Representation of Identity. London: SAGE Publications.

Curtis, Ric 2002. Coexisting in the Real World: The Problems, Surprises and Delights of Being an Ethnographer on a Multidisciplinary Research Project. The International Journal of Drug Policy, Vol. 13, No. 2, pp. 297-310. http://dx.doi.org/10.1016/ S0955-3959(02)00116-0.

Fetterman, David M. 1989. Ethnography: Step-by-Step. London: SAGE Publications.

Geertz, Clifford 1973. The Interpretation of Cultures. New York: Basic Books.

Giddens, Anthony 1991. Modernity and Self-Identity: Self and Society in the Late Modern Age. Oxford: Polity Press.

Giddens, Anthony 1999. Runaway World. London: Profile Books.

Gololobov, Ivan 2014. On Being a Punk and a Scholar: A Reflexive Account of Researching Punk Scene in Russia. Sociological Research Online, Vol. 19, No. 4, pp. 1-13. doi: $10.5153 /$ sro.3486.

Gololobov, Ivan \& Pilkington, Hilary \& Steinholt, Yngvar B. 2014. Punk in Russia: Cultural Mutation from the 'Useless' to the 'Moronic'. London \& New York: Routledge.

Griffin, Christine \& Bengry-Howell, Andrew \& Hackley, Chris \& Mistral, Willm \& Szmigin, Isabelle 2009. 'Every Time I Do It, I Absolutely Annihilate Myself': Loss of (Self-)Consciousness and Loss of Memory in Young People's Drinking Narratives. Sociology, Vol. 43, No. 3, pp. 457-476. doi:10.1177/0038038509103201. 
Hayward, Keith 2002. The Vilification and Pleasures of Youthful Transgression. In: J. Muncie \& G. Hughes \& E. MacLaughlin (eds.) Youth Justice: Critical Readings. London: SAGE Publications, pp. 80-94. Available at http://blogs. kent.ac.uk/culturalcriminology/files/2011/03/hayward-vilif.pdf, last accessed on April 24, 2015.

Hesse, Morten \& Tutenges, Sébastien \& Schliewe, Sanna \& Reinholdt, Tine 2008. Party Package Travel: Alcohol Use and Related Problems in a Holiday Resort: A Mixed Methods Study. BMC Public Health, Vol. 8, pp. 351-358. doi:10.1186/1471-24588-351.

Israel, Mark 2004. Strictly Confidential? Integrity and the Disclosure of Criminological and Socio-Legal Research. British Journal of Criminology, Vol. 44, No. 5, pp. 715-740. http://dx.doi.org/10.1093/bjc/azh033.

Israel, Mark \& Hay, Iain 2006. Research Ethics for Social Scientist. London \& Thousand Oaks \& New Dehli: SAGE Publications.

Lee-Treweek, Geraldine \& Linkogle, Stephanie 2000. Danger in the Field: Risk and Ethics in Social Research. London: Routledge.

Maher, Lisa 2002. Don't Leave Us This Way: Ethnography and Injecting Drug Use in the Age of AIDS. International Journal of Drug Policy, Vol. 13, No. 4, pp. 311-325. doi:10.1016/S0955-3959(02)00118-4.

Palmer, Catherine \& Thomson, Kirrilly 2010. Everyday Risks and Professional Dilemmas: Fieldwork with Alcohol-Based (Sporting) Subcultures. Qualitative Research, Vol. 10, No. 4, pp. 421-440. doi: 10.1177/1468794110366800.

Patton, Michael Q. 1990. Qualitative Evaluation and Research Methods. Second Edition. Newbury Park, CA: SAGE Publications.

Power, Robert 2002. The Application of Ethnography, with Reference to Harm Reduction in Sverdlovsk Russia. The International Journal of Drug Policy, Vol. 13, No. 4, pp. 327-331. http://dx.doi.org/10.1016/S0955-3959(02)00117-2.

Preble, Edward \& Casey, John J. 1969. Taking Care of Business: The Heroin User's Life on the Street. The International Journal of the Addictions, Vol. 4, No. 1, pp. 1-24. http://dx.doi.org/10.3109/10826086909061998.

Rubin, Vera \& Comitas, Lambros 1975. Ganja in Jamaica: A Medical Anthropological Study of Chronic Marihuana Use. The Hague \& Paris: Mouton.

Sanjek, Roger 2000. Keeping Ethnography Alive in an Urbanizing World. Human Organization, Vol. 59, No. 3, pp. 280-288.

Tutenges, Sébastien \& Hesse, Morten 2008. Patterns of Binge Drinking at an International Nightlife Resort. Alcohol and Alcoholism, Vol. 43, No. 5, pp. 595-599. http://dx.doi.org/10.1093/alcalc/agn039.

Vanderstaay, Steven 2005. One Hundred Dollars and a Dead Man: Ethical DecisionMaking in Ethnographic Fieldwork. Journal of Contemporary Ethnography, Vol. 34, No. 4, pp. 371-409. http://dx.doi.org/10.1177/0891241605275478.

Van Maanen, John 1988. Tales of the Field: On Writing Ethnography. Chicago: University of Chicago Press. 
Ventsel, Aimar 2008. Punx and Skins United: One Law For Us One Law For Them. The Journal of Legal Pluralism and Unofficial Law, Vol. 40, No. 57, pp. 45-100. http://dx.doi.org/10.1080/07329113.2008.10756618.

Ward, Jennifer R. 2010. Flashback: Drugs and Dealing in the Golden Age of the London Rave Scene. Cullumpton: Willan Publishing.

Willis, Paul E. 1977. Learning to Labor: How Working Class Kids Get Working Class Jobs. Columbia: Columbia University Press.

Young, Jock 1971. The Drugtakers: The Social Meaning of Drug Use. London: Paladin. 